\begin{tabular}{ll}
\hline Homepage: http://jusami.batan.go.id & Jurnal Sains Materi Indonesia \\
\hline & $\begin{array}{l}\text { Akreditasi LIPI } \\
\text { No.: 602/AU3/P2MI-LIPI/03/2015 } \\
\text { Tangal 15 April 2015 } \\
\text { ISSN 1411-1098 }\end{array}$ \\
\hline
\end{tabular}

\title{
PENGARUH SUHU DAN WAKTU PEMANASAN TERHADAP KARAKTERISTIK LAPISAN ELEKTROLES Ni-P PADA BAJA TAHAN KARAT MARTENSITIK SS 420
}

\author{
Bahtiar Nurhakim ${ }^{1}$, Arini Nikitasari ${ }^{2}$, Sunardi $^{1}$ dan Efendi Mabruri $^{2}$ \\ ${ }^{1}$ Universitas Sultan Ageng Tirtayasa \\ Jl. Jendral Soedirman Km.3, Cilegon \\ ${ }^{2}$ Pusat Penelitian Metalurgi dan Material - LIPI \\ Kawasan Puspiptek Gd.470, Tangerang Selatan \\ E-mail: arini_nikitasari@yahoo.com
}

Diterima: 17 Februari 2017

Diperbaiki: 25 April 2017

Disetujui: 3 Mei 2017

\begin{abstract}
ABSTRAK
PENGARUH SUHU DAN WAKTU PEMANASAN TERHADAP KARAKTERISTIK LAPISAN ELEKTROLES Ni-P PADA BAJA TAHAN KARAT MARTENSITIK SS 420. Telah dilakukan pelapisan elektroles Nikel-Posfor (Ni-P) pada baja tahan karat martensitik SS 420 dengan berbagai variasi suhu dan waktu perlakuan panas. Karakteristik lapisan elektroles Ni-P yang berupa strukturmikro dan ketahanan korosi dianalisis untuk mengetahui pengaruh variasi suhu dan waktu pemanasan. Variasi suhu perlakuan panas yang digunakan yaitu $200{ }^{\circ} \mathrm{C}, 300{ }^{\circ} \mathrm{C}, 400{ }^{\circ} \mathrm{C}$, dan $500{ }^{\circ} \mathrm{C}$, sedangkan variasi waktu pemanasan yang digunakan antara lain 60 menit, 120 menit, dan 180 menit. Hasil yang diperoleh menunjukkan bahwa kenaikan suhu dan waktu pemanasan menyebabkan lapisan elektroles Ni-P yang terbentuk menjadi lebih seragam dan ketahanan material terhadap korosi semakin meningkat. Terjadi peningkatan kadar unsur Nikel dan Posfor dalam lapisan elektroles Ni-P dengan adanya perlakuan panas. Kadar unsur Nikel dan Posfor tertinggi pada suhu pemanasan $400{ }^{\circ} \mathrm{C}$ dan waktu pemanasan selama 180 menit.
\end{abstract}

Kata kunci: Elektroles, Nikel-Posfor, Martensitik, Korosi

\begin{abstract}
EFFECT OF TEMPERATURE AND HEATING TIME ON THE COATING CHARACTERISTICS OF MARTENSITIC SS 420 ELECTROLESS Ni-P. Electroless nickel phosphorus (Ni-P) coating has been done on the martensitic stainless steel SS 420 with a variety of temperature and heating time. Electroless Ni-P coating characteristics; microstructure and corrosion resistance were analyzed to determine the effect of variations in temperature and heating time. Variations in the temperature of the heat treatment used are $200{ }^{\circ} \mathrm{C}, 300{ }^{\circ} \mathrm{C}$, $400{ }^{\circ} \mathrm{C}$ and $500{ }^{\circ} \mathrm{C}$, while the variation of heating time is used, 60 minutes, 120 minutes and 180 minutes. The results showed that the rise in temperature and heating time causes electroless Ni-P coating becomes more uniform and corrosion resistance of material is also increasing. Nickel and phosphorus elements in electroless coating of Ni-P increased with heat treatment. The highest nickel and phosphorus elements obtained at $400{ }^{\circ} \mathrm{C}$ heating temperature and 180 minute heating time.
\end{abstract}

Keywords: Electroless, Nickel-Phosphor, Martensitic, Corrosion

\section{PENDAHULUAN}

Strategi pencegahan untuk mengurangi tingginya biaya reparasi akibat korosi menjadi menarik untuk dibahas. Berbagai teknologi telah digunakan untuk mengontrol terjadinya fenomena korosi. Salah satu cara yang dapat digunakan untuk mengurangi laju korosi yaitu teknik pelapisan (coating) [1]. Proses pelapisan (coating) merupakan metode yang populer untuk melindungi material dari korosi. Deposisi pelapisan pada umumnya dilakukan dalam larutan elektrolit atau elektroles [2]. 
Elektroles ditemukan oleh Brenner dan Riddle untuk melapisi bagian dalam pipa pada tahun 1946, selanjutnya elektroles banyak diaplikasikan pada berbagai material seperti kayu, serat, plastik, kertas, kaca, dan keramik pada tahun 1960-an. Elektroles merupakan teknik pelapisan tanpa menggunakan arus listrik [3]. Elektroles merupakan proses reduksi kimia yaitu reduksi katalitik ion logam dari larutan yang mengandung agent pereduksi [4].

Deposisi elektroles, seperti $\mathrm{Ag}, \mathrm{Au}, \mathrm{Cu}, \mathrm{Pt}$, dan elektroles nikel posfor (ENP), banyak digunakan dalam industri karena dapat menghasilkan lapisan yang seragam untuk berbagai komponen, serumit apapun bentuk komponen tersebut. Di antara berbagai jenis elektroles, ENP merupakan teknik pelapisan yang dapat diaplikasikan pada berbagai jenis material seperti quartz dan polimer [5].

Elektroles nikel posfor (ENP) banyak diaplikasikan dalam industri untuk melapisi valve, peralatan medis, dan silinder hidrolik karena sifat mekanik dan fisiknya yang unggul serta kemampuannya dalam mencegah keausan dan korosi [6-10]. Sifat dan strukturmikro ENP tergantung pada kadar unsur posfor pada lapisan yang terbentuk dan perlakuan panas setelah proses elektroles selesai dilakukan. Struktur lapisan ENP terdiri dari tiga macam yaitu kristalin, amorf, dan gabungan keduanya.

Secara umum, kadar posfor rendah $(1-5 \% \mathrm{P})$ berstruktur mikrokristalin, kadar posfor sedang (6-9\% P) berstruktur gabungan antara kristalin dan amorf, dan kadar posfor tinggi (10-13\% P) berstruktur amorf. Kadar posfor tinggi pada ENP mengindikasikan keunggulannya dalam mencegah korosi, tetapi kekerasan dan ketahanan aus nya lebih rendah dibanding ENP dengan kadar posfor rendah [6].

Perlakuan panas pada ENP juga mempengaruhi sifat lapisan yang terbentuk, antara lain sifat adesif dan kekerasannya [11]. Selama ini, penelitian mengenai elektroles $\mathrm{Ni}-\mathrm{P}$ banyak berfokus pada rekayasa permukaan dan optimasi berbagai parameter percobaan elektroles seperti komposisi nikel dan agent pereduksi yang digunakan [10]. Oleh karena itu, pada penelitian ini, dilakukan variasi suhu dan waktu perlakuan panas untuk mengetahui pengaruhnya terhadap karakteristik lapisan ENP pada baja tahan karat martensitik SS 420.

Penggunaan baja tahan karat martensitik SS 420 pada penelitian ini dikarenakan material SS 420 banyak digunakan sebagai material pada sudu turbin uap. Sudu turbin bekerja pada putaran tinggi dan lingkungan yang korosif sehingga material sudu turbin SS 420 rentan mengalami kegagalan berupa korosi sumuran, fatik korosi, dan korosi retak tegang [12]. Oleh karenanya dilakukan pelapisan elektroless Ni-P pada SS 420 dengan tujuan untuk menambah ketahanannya terhadap korosi sehingga dapat menambah umur turbin uap.

\section{METODE PERCOBAAN}

\section{Preparasi Benda Uji}

Material yang digunakan dalam penelitian ini adalah baja tahan karat martensitik SS 420. Tabel 1. menunjukkan komposisi kimia dari baja tahan karat martensitik SS 420.

Tabel 1. Komposisi kimia baja tahan karat Martensit SS 420.

\begin{tabular}{cccccccc}
\hline \multicolumn{7}{c}{ Komposisi Kimia (\% Berat) } \\
\hline $\mathrm{C}$ & $\mathrm{Si}$ & $\mathrm{S}$ & $\mathrm{P}$ & $\mathrm{Mn}$ & $\mathrm{Ni}$ & $\mathrm{Cr}$ & $\mathrm{Fe}$ \\
0,43 & 0,26 & 0,02 & 0,02 & 0,37 & 0,15 & 12,41 & Bal. \\
\hline
\end{tabular}

Preparasi benda uji dilakukan dengan memotong material baja tahan karat martensitik SS 420 yang berbentuk silinder menjadi bentuk persegi dengan ukuran $2 \mathrm{~cm}$ x $2 \mathrm{~cm}$. Selanjutnya benda uji diberi lubang sebagai tempat untuk menggantungkan ketika proses elektroles dilakukan.

\section{Elektroles Nikel-Posfor}

Sebelum proses elektroles nikel-posfor dimulai, dilakukan pre-treatment terlebih dahulu terhadap benda uji. Pertama-tama, permukaan benda uji dibersihkan secara mekanik dari produk korosi dan dibersihkan menggunakan deterjen lalu dibilas menggunakan air suling. Selanjutnya, benda uji direndam dalam $10 \mathrm{~mL}$ $\mathrm{HNO}_{3}, 20 \mathrm{~mL} \mathrm{HCl}$, dan $30 \mathrm{~mL} \mathrm{H}_{2} \mathrm{O}$ pada suhu ruang selama 2 menit lalu dibilas menngunakan air suling. Setelah itu, benda uji diaktivasi menggunakan $0,6 \mathrm{~g} / \mathrm{L}$ $\mathrm{PdCl}_{2}+5 \mathrm{~mL} \mathrm{HCl}$ pada suhu ruang selama 10 menit lalu direndam dalam air suling selama 1 menit. Terakhir, benda uji dimasukkan ke dalam larutan $50 \mathrm{~g} / \mathrm{L} \mathrm{NaH}_{2} \mathrm{PO}_{2}$ selama 10 menit dan dibilas menggunakan air suling.

Setelah proses pre-treatment terhadap benda uji selesai dilakukan, benda uji dimasukkan ke dalam larutan elektroles nikel-posfor. Larutan elektroles nikel-posfor memiliki komposisi kimia seperti pada Tabel 2. Benda uji direndam dalam larutan elektroles nikel-posfor selama 120 menit. Waktu pelapisan selama 120 menit ini dipilih karena merupakan waktu optimum berdasarkan penelitian pendahuluan yang telah kami lakukan.

Tabel 2. Komposisi kimia elektroles Nikel-Posfor [11].

\begin{tabular}{lc}
\hline Komposisi & Konsentrasi $(\mathrm{g} / \mathrm{l})$ \\
\hline Nikel Sulfat $\left(\mathrm{NiSO}_{4} \cdot 6 \mathrm{H}_{2} \mathrm{O}\right)$ & 35 \\
Sodium hipoposfit $\left(\mathrm{NaH}_{2} \mathrm{PO}_{2} \cdot \mathrm{H}_{2} \mathrm{O}\right)$ & 20 \\
Sodium citrat $\left(\mathrm{Na}_{3} \mathrm{C}_{6} \mathrm{H}_{5} \mathrm{O}_{7}\right)$ & 15 \\
Sodium acetat $\left(\mathrm{NaOOCCH}_{3} \cdot 3 \mathrm{H}_{2} \mathrm{O}\right)$ & 5 \\
\hline
\end{tabular}

\section{Perlakuan Panas}

Benda uji yang telah terlapisi oleh elektroles nikelposfor diberikan perlakuan panas dengan variasi suhu 
Pengaruh Suhu dan Waktu Pemanasan Terhadap Karakteristik Lapisan Elektroles Ni-P Pada Baja Tahan Karat Martensitik SS 420 (Bahtiar Nurhakim)

$200^{\circ} \mathrm{C}, 300^{\circ} \mathrm{C}, 400^{\circ} \mathrm{C}$, dan $500^{\circ} \mathrm{C}$, variasi waktu perlakuan panas selama 60 menit, 120 menit dan 180 menit.

\section{HASIL DAN PEMBAHASAN}

Karakterisasi lapisan Ni-P yang terbentuk berupa strukturmikro dan korosi dianalisis pada percobaan ini untuk mengetahui keseragaman lapisan dan ketahanan korosi material akibat adanya pelapisan. Hasil analisis karakterisasi lapisan yang terbentuk diharapkan memiliki strukturmikro yang seragam dan laju korosi yang rendah sehingga dapat menambah umur pakai material SS 420 sebagai sudu turbin uap, seperti diperlihatkan pada Gambar 1.

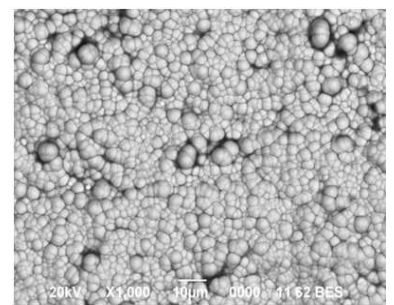

Gambar 1. Sturkturmikro lapisan tanpa perlakuan panas pembesaran 1000x.

\section{Analisis Morfologi}

Alat yang digunakan dalam analisa morfologi adalah Scanning Electron Microscopy (SEM). Pengujian ini dilakukan untuk mengetahui bentuk butiran ,unsur yang terkandung, serta melihat perbandingan lapisan yang melalui dan tanpa melalui proses perlakuan panas, seperti diperlihatkan pada Gambar 2 sampai dengan Gambar 4.

Berdasarkan gambar morfologi di atas, pada setiap suhu pemanasan cenderung terjadi keseragaman lapisan elektroles Ni-P seiring penambahan waktu pemanasan. Keseragaman lapisan elektroless Ni-P dapat terlihat berdasarkan gambar SEM yaitu butiran-butiran lapisan nikel-posfor menutupi permukaan substrat secara merata.
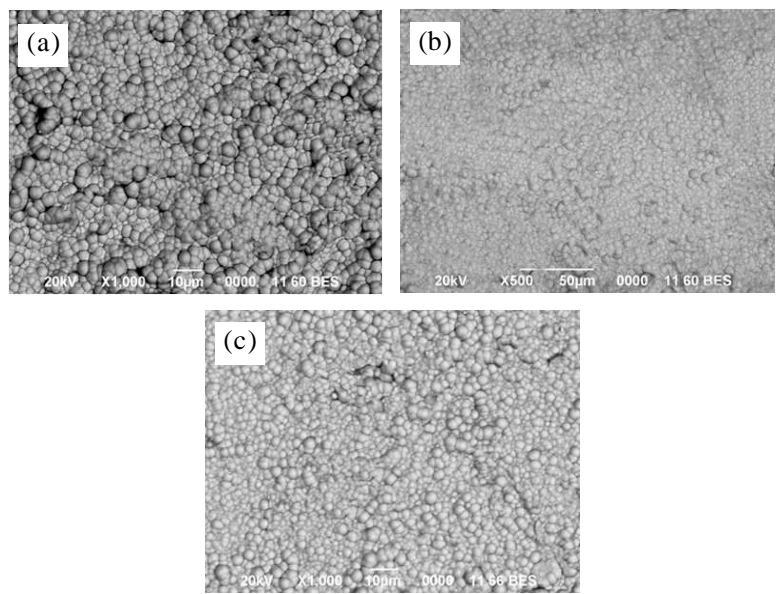

Gambar 2. Lapisan Ni-P setelah perlakuan panas pada suhu $200{ }^{\circ} \mathrm{C}$ dengan variasi waktu (a). 60 menit (b). 120 menit (c). 180 menit.
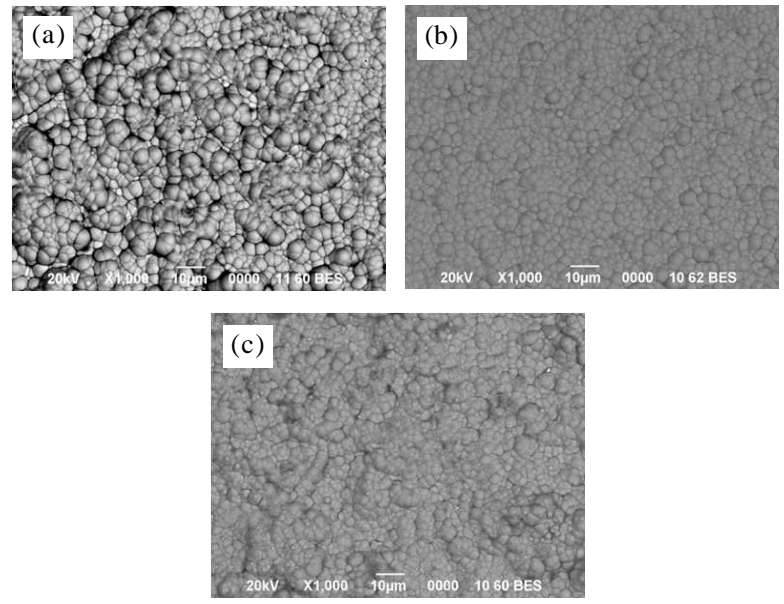

Gambar 3. Lapisan Ni-P setelah perlakuan panas pada suhu $300{ }^{\circ} \mathrm{C}$ dengan variasi waktu (a). 60 menit (b). 120 menit (c). 180 menit.
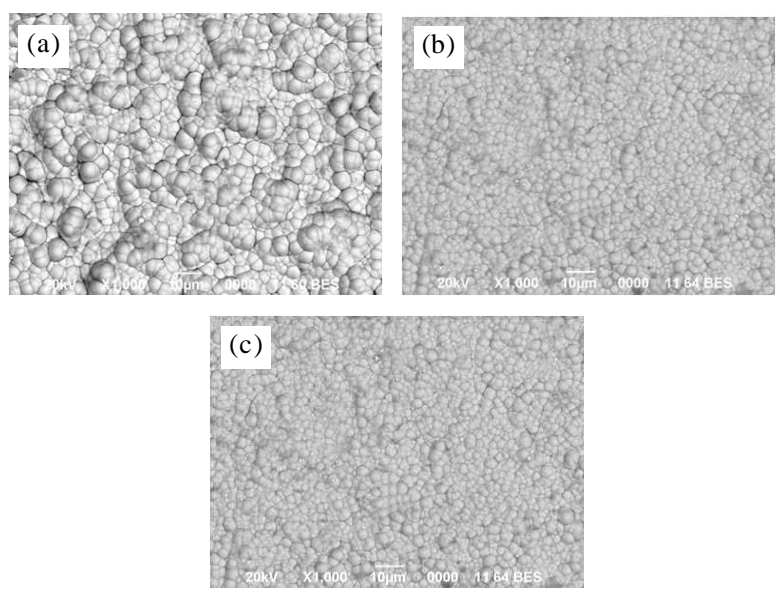

Gambar 4. Lapisan Ni-P setelah perlakuan panas pada suhu $400{ }^{\circ} \mathrm{C}$ dengan variasi waktu (a). 60 menit (b). 120 menit (c). 180 menit.

Hal ini terjadi karena durasi atom-atom untuk berdifusi menjadi lebih panjang, pada lapisan Ni-P. Pada suhu pemanasan $500{ }^{\circ} \mathrm{C}($ Gambar 5(a)) terjadi oksidasi yang menyebabkan permukaan lapisan terbakar dan menjadi
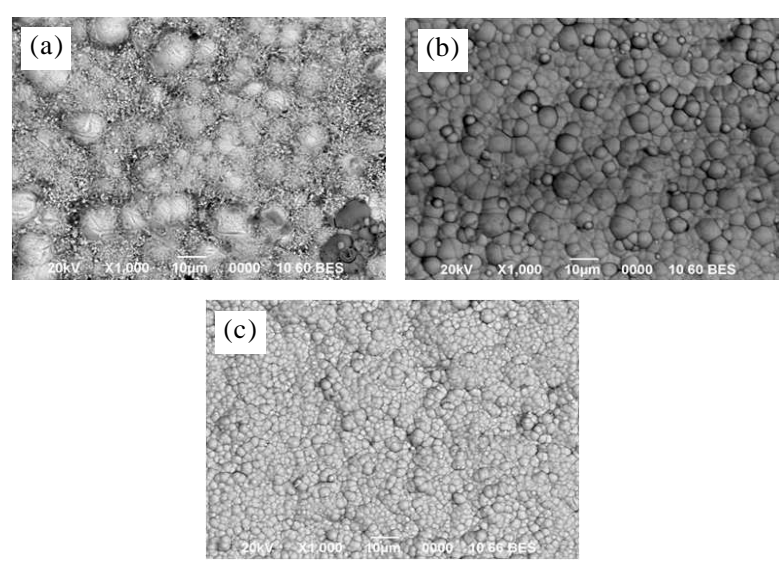

Gambar 5. Lapisan Ni-P setelah perlakuan panas pada suhu $500{ }^{\circ} \mathrm{C}$ dengan variasi waktu (a). 60 menit (b). 120 menit (c). 180 menit. 
hitam. Struktur lapisan yang terlihat pun berbeda karena pada lapisan permukaan telah terjadi oksidasi, pada suhu $500{ }^{\circ} \mathrm{C}$ unsur $\mathrm{Ni}$ dan $\mathrm{P}$ memiliki kecenderungan untuk meningkatkan kekerasan permukaan sehingga dalam proses perlakuan panas memerlukan bantuan karbon untuk menghindari terjadinya oksidasi. Sehingga pada proses pemanasan $500{ }^{\circ} \mathrm{C}$ selama 120 dan 180 menit proses pemanasan menggunakan karbon. Struktur lapisan Ni-P yang terbentuk cenderung sama dan seragam seperti pada suhu $400^{\circ} \mathrm{C}$.

\section{Korelasi Suhu Perlakuan Panas Terhadap Komposisi Nikel dan Posfor}

Untuk mengetahui seberapa besar Nikel dan Posfor yang terdapat pada permukaan lapisan dilakukan pengujian Scanning Electron Microscopy Energy Dispersive $X$-ray (SEM EDX). Setelah melakukan pengujian didapatlah hasil seperti pada Tabel 3 hingga Tabel 7.

Dari analisis $E D X$ terdapat kandungan posfor beragam, dirata-ratakan komposisi di atas 5,5\% dikategorikan medium posfor [6].

Tabel 3. Komposisi (\%) Ni , dan $\mathrm{P}$ pada lapisan tanpa perlakuan panas.

\begin{tabular}{lc}
\hline Unsur & Komposisi (\%) \\
\hline Nikel & 78,85 \\
Posfor & 5,70 \\
\hline
\end{tabular}

Tabel 4. Komposisi (\%) Ni dan $\mathrm{P}$ pada lapisan dengan suhu perlakuan panas $200{ }^{\circ} \mathrm{C}$.

\begin{tabular}{ccc}
\hline Waktu & $\mathrm{Ni}$ & $\mathrm{P}$ \\
\hline 60 menit & 85,03 & 5,79 \\
120 menit & 90,01 & 6,45 \\
180 menit & 90,15 & 6,50 \\
\hline
\end{tabular}

Tabel 5. Komposisi (\%) Ni dan $\mathrm{P}$ pada lapisan dengan suhu perlakuan panas $300{ }^{\circ} \mathrm{C}$.

\begin{tabular}{ccc}
\hline Waktu & $\mathrm{Ni}$ & $\mathrm{P}$ \\
\hline 60 menit & 89,58 & 6,31 \\
120 menit & 90,60 & 6,49 \\
180 menit & 91,82 & 6,97 \\
\hline
\end{tabular}

Tabel 6. Komposisi (\%) Ni dan $\mathrm{P}$ pada lapisan dengan suhu perlakuan panas $400{ }^{\circ} \mathrm{C}$.

\begin{tabular}{ccc}
\hline Waktu & $\mathrm{Ni}$ & $\mathrm{P}$ \\
\hline 60 menit & 90,01 & 6,39 \\
120 menit & 90,89 & 6,59 \\
180 menit & 92,32 & 7,38 \\
\hline
\end{tabular}

Tabel 7. Komposisi (\%) Ni dan $\mathrm{P}$ pada lapisan dengan suhu perlakuan panas $500{ }^{\circ} \mathrm{C}$.

\begin{tabular}{ccc}
\hline Waktu & $\mathrm{Ni}$ & $\mathrm{P}$ \\
\hline 60 menit & 90,05 & 2,64 \\
120 menit & 91,45 & 6,51 \\
180 menit & 92,25 & 6,88 \\
\hline
\end{tabular}

Berdasarkan grafik pada Gambar 6, terdapat peningkatan unsur posfor dengan meningkatnya suhu perlakuan panas, peningkatan berada di kisaran $0,1-0,8 \%$. Secara langsung temperatur kamar dapat meningkatkan atau menurunkan ketersediaan posfor. Pada temperatur yang relatif tinggi, ketersediaan posfor akan meningkat karena proses perombakan bahan unsur posfor di lingkungan juga meningkat. Ketersediaan posfor menipis di kondisi lingkungan yang bersuhu rendah. Pada suhu $500{ }^{\circ} \mathrm{C}$ kandungan posfor menurun drastis akibat melemahnya ikatan atom-atom akibat terjadinya transformasi fasa metastabil nikel-posfor menjadi fasa campuran larutan padat nikel $\mathrm{Ni}-\mathrm{Ni}_{3} \mathrm{P}$ (dengan kandungan posfor yang sangat rendah). Oleh karena itu, komposisi nikel dan posfor terbaik berada pada suhu $400{ }^{\circ} \mathrm{C}$ karena di atas $400{ }^{\circ} \mathrm{C}$, ikatan atom-atom dalam fasa nikel sangat lemah.

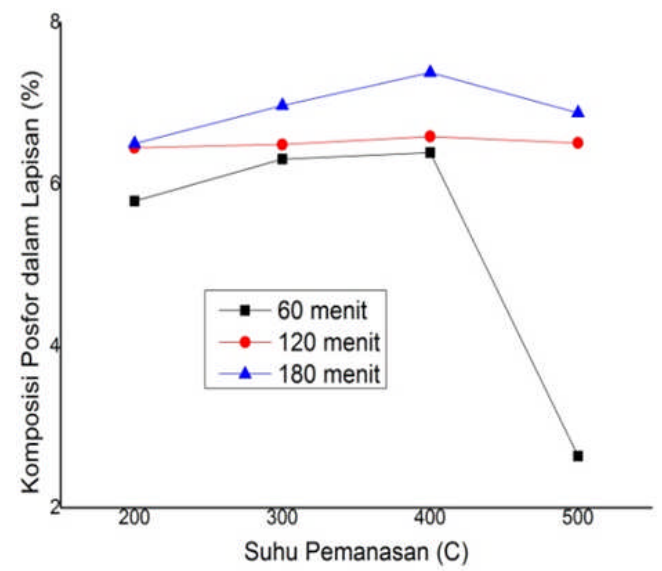

Gambar 6. Korelasi suhu pemanasan terhadap prosentase komposisi posfor pada lapisan Ni-P.

Berdasarkan Gambar 7, kandungan nikel pada lapisan dengan perlakuan panas mengalami kenaikan yang signifikan dibandingkan lapisan tanpa perlakuan panas. Kenaikan berada pada kisaran 0,2 - $5 \%$, kenaikan cenderung stabil pada suhu $300-400^{\circ} \mathrm{C}$. Kenaikan nikel terjadi akibat kenaikan densitas. Densitas merupakan kerapatan penyusun sampel, sehingga keberadaan sedikit ruang kosong akan mempengaruhi kerapatan padatan berpori dan akan mempengaruhi perbandingan

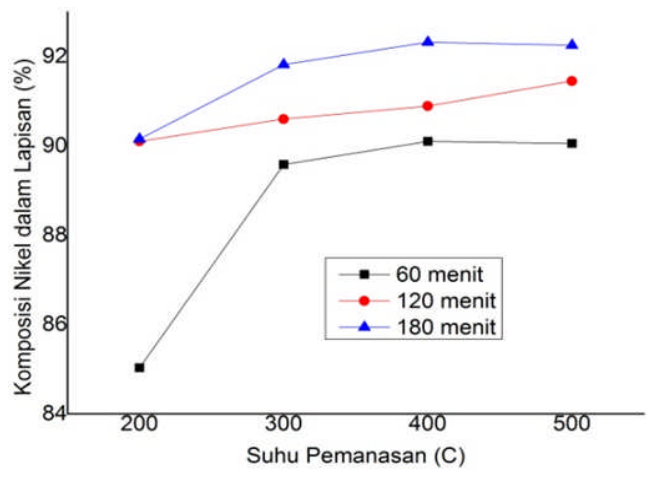

Gambar 7. Korelasi suhu pemanasan terhadap prosentase komposisi nikel pada lapisan Ni-P. 
dari berat per volume sampel. Nilai densitas cenderung bertambah dengan kenaikkan temperatur pemanasan [13].

\section{Korelasi Waktu Perlakuan Panas Terhadap Komposisi Nikel dan Posfor}

Gambar 8 menunjukan perubahan komposisi Posfor pada setiap waktu pemanasan. Seiring bertambahnya waktu pemanasan, cenderung terjadi peningkatan komposisi posfor yang terkandung pada lapisan. Hal ini di sebabkan lamanya waktu pemanasan memungkinkan atom-atom untuk bergerak mengisi kekosongan menjadi lebih panjang, sehingga atom posfor yang terbentuk lebih seragam [14]. Pada saat pemanasan selama 120 menit pengaruh suhu terlihat tidak terlalu dominan.

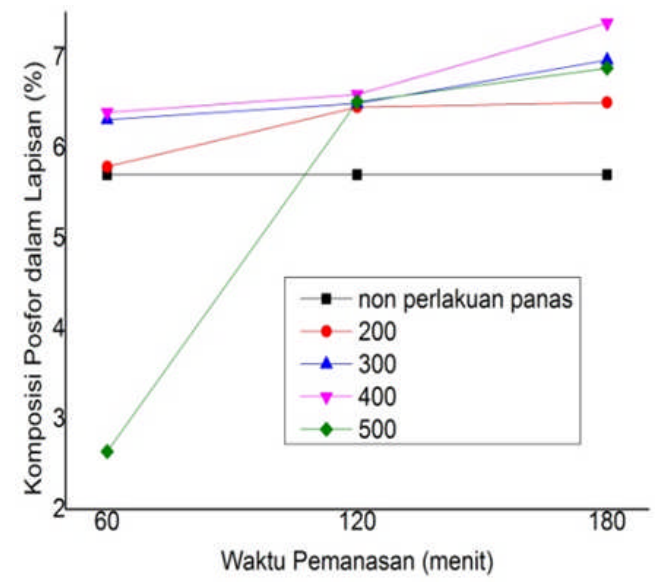

Gambar 8. Korelasi waktu pemanasan terhadap prosentase komposisi posfor pada lapisan Ni-P.

Gambar 9 menunjukan perubahan komposisi Nikel pada setiap waktu pemanasan. Seiring bertambahnya waktu pemanasan, cenderung terjadi peningkatan komposisi Nikel yang terkandung pada lapisan. Hal ini disebabkan lamanya waktu pemanasan memungkinkan atom-atom untuk bergerak mengisi kekosongan menjadi lebih panjang [14], sehingga atom Nikel yang terbentuk lebih seragam.

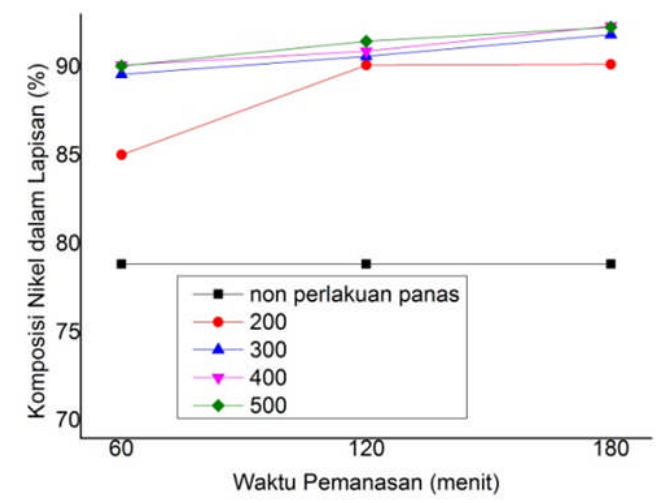

Gambar 9. Korelasi waktu pemanasan terhadap prosentase komposisi nikel pada lapisan Ni-P.

\section{Analisa ketahanan laju korosi lapisan Ni-P}

Untuk mengetahui ketahanan korosi pada permukaan coating, dilakukan pengujian laju korosi Corrosion Measurement System (CMS) Pengujian ini dilakukan dengan menggunakan media larutan $\mathrm{NaCl}$ sebanyak 8,75 gr dalam $250 \mathrm{~mL}$ aquades atau 3,5\% NaCl. Material yang akan diuji perlu dihubungkan dengan kabel dengan cara dipatri (solder) dan diukur luasan area $\left(\mathrm{cm}^{2}\right)$ yang akan diberikan arus listrik. Pengujian dilakukan pada sampel yang telah melalui proses perlakuan panas dengan material yang tidak melalui proses perlakuan panas untuk melihat perubahan yang terjadi.

Hasil pengujian menunjukkan nilai laju korosi yang memiliki satuan mmpy, yakni seberapa besar ketebalan pengikisan material akibat korosi dalam rentang 1 tahun. Semakin besar nilai corrosion rate semakin mudah material mengalami korosi, seperti diperlihatkan pada Tabel 8.

Tabel 8. Nilai laju korosi (mmpy).

\begin{tabular}{cccccc}
\hline $\begin{array}{c}\text { Waktu } \\
\text { (menit) }\end{array}$ & $\begin{array}{c}200 \\
\left({ }^{\circ} \mathrm{C}\right)\end{array}$ & $\begin{array}{c}300 \\
\left({ }^{\circ} \mathrm{C}\right)\end{array}$ & $\begin{array}{c}400 \\
\left({ }^{\circ} \mathrm{C}\right)\end{array}$ & $\begin{array}{c}500 \\
\left({ }^{\circ} \mathrm{C}\right)\end{array}$ & Tanpa \\
\hline 60 & 0,0384 & 0,01618 & - & - & 0,05844 \\
120 & 0,0287 & 0,01597 & 0,01517 & 0,01064 & 0,05844 \\
180 & 0,0249 & 0,0157 & 0,01428 & 0,0122 & 0,05844 \\
\hline
\end{tabular}

Berdasarkan Gambar 10 menunjukkan penurunan nilai laju korosi, yang berarti ketahanan material terhadap korosi semakin meningkat. Hal ini disebabkan peningkatan dari unsur Nikel dan juga Posfor pada lapisan, karena kandungan nikel sangat berperan penting untuk meningkatkan ketahanan korosi dalam media pengkorosi netral atau lemah. Nikel juga meningkatkan keuletan dan mampu meningkatkan ketahanan korosi tegangan, sedangkan posfor membantu mencegah terjadinya proses oksidasi pada udara luar yang dapat menyebabkan terjadi korosi. Sehingga penambahan unsur Nikel dan Posfor berperan dalam peningkatan ketahanan laju korosi lapisan.

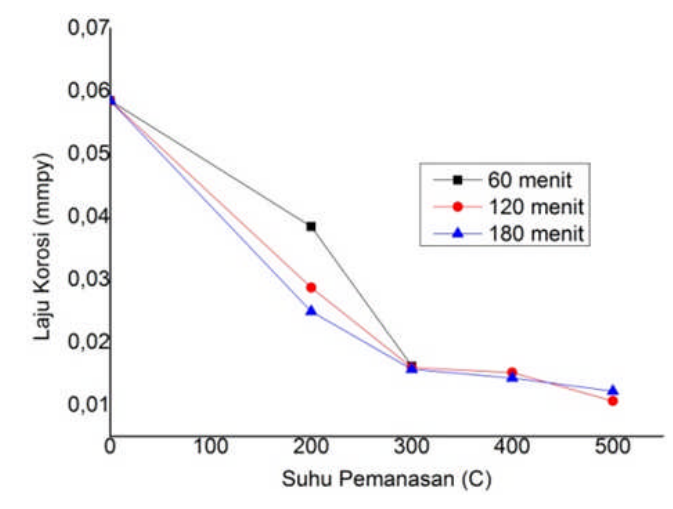

Gambar 10. Grafik nilai laju korosi terhadap suhu pemanasan dalam mmpy.

Bedasarkan Gambar 11 diatas terlihat pengaruh waktu pemanasan cukup berperan guna menurunkan nilai 


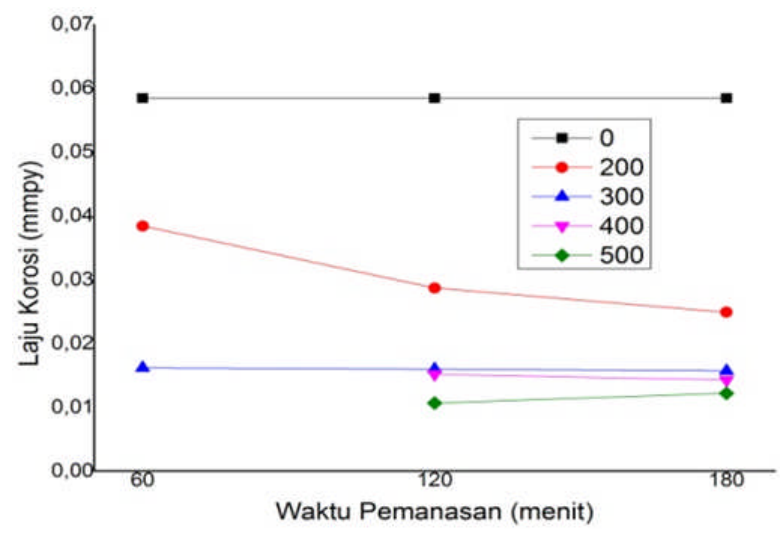

Gambar 11. Grafik nilai laju korosi terhadap waktu pemanasan dalam mmpy.

laju korosi, terutama pada suhu $200^{\circ} \mathrm{C}$ terjadi penurunan signifikan.Akan tetapi hal ini tidak berpengaruh terlalu besar pada suhu $300{ }^{\circ} \mathrm{C}$ dan $400{ }^{\circ} \mathrm{C}$, ini di karenakan peningatan kandungan $\mathrm{Ni}$ dan $\mathrm{P}$ yang tidak terlalu tinggi.

\section{KESIMPULAN}

Dari hasil penelitian pengaruh suhu dan waktu pemanasan terhadap karakteristik lapisan elektroles Ni-P pada baja tahan karat martensit SS 420, disimpulkan bahwa kenaikan suhu dan waktu pemanasan menyebabkan butiran lapisan Ni-P yang terbentuk semakin seragam. Perlakuan panas menyebabkan komposisi nikel dan posfor semakin tinggi dalam lapisan elektroles, dimana kandungan posfor dan nikel tertinggi dicapai pada suhu pemanasan $400{ }^{\circ} \mathrm{C}$ dengan waktu pemanasan selama 180 menit. Kenaikan suhu dan waktu pemanasan meningkatkan ketahanan material terhadap korosi. Nilai laju korosi tertinggi pada material yang tidak mengalami proses perlakuan panas yakni sebesar 0,05844 mmpy. Sedangkan nilai laju korosi terendah sebesar 0,01064 mmpy yakni pada spesimen dengan suhu pemanasan $500{ }^{\circ} \mathrm{C}$ dan 120 menit.

\section{UCAPAN TERIMAKASIH}

Penulis dengan tulus mengucapkan terima kasih kepada Pusat Penelitian Metalurgi dan Material LIPI yang telah mendanai penelitian ini melalui mekanisme kegiatan Tematik 2016.

\section{DAFTAR ACUAN}

[1] Z. Sharifalhoseini and M. H. Entezari. "Applied Surface Science Enhancement of the Corrosion Protection of Electroless Ni-P Coating by Deposition of Sonosynthesized ZnO Nanoparticles.” Appl. Surf. Sci., vol. 351, pp. 1060-1068. 2015.
[2]. B. Panja and P. Sahoo. "Wear Behavior of Electroless Ni-P Coatings in Brine Solution and Optimization of Coating Parameters." Procedia Technol., vol. 14, pp. 173-180. 2014.

[3]. I. Kwon, H. Kim, and S. Bum. "Journal of Industrial and Engineering Chemistry Optimization of Barrel Plating Process for Electroless Ni-P plating." J. Ind. Eng. Chem., vol. 20, no. 5, pp. 3767-3774. 2014.

[4]. E. L. C. O. Eposition, “Al 2 O 3 D,” 2016.

[5]. M. Zhang, S. Mu, Q. Guan, W. Li, and J. Du. "Applied Surface Science A High Anticorrosive Chromium-Free Conversion Coating Prepared with an Alkaline Conversion Bath on Electroless Ni-P Coating." Appl. Surf. Sci., vol. 349, no. 2015, pp. 108-115, 2017.

[6]. R. Taheri, I. N. A. Oguocha, and S. Yannacopoulos. "The Tribological Characteristics of Electroless Nip Coatings," vol. 249, no. January, pp. 389-396, 2001.

[7]. H. Liu, Y. Y. Lv, Z. Liu, H. Liu, and G. E. Thompson. "Tribology International Dry Sliding Wear Behaviour and Structural Characteristics of LaserAnnealed Electroless Ni-P/Ni-Mo-P Duplex Coatings." vol. 103, pp. 343-351, 2016.

[8]. W. Wang, W. Zhang, Y. Wang, N. Mitsuzak, and Z. Chen. "Applied Surface Science Ductile electroless Ni-P Coating Onto Flexible Printed Circuit Board." Appl. Surf. Sci., vol. 367, pp. 528-532, 2016.

[9]. J. Wojewoda-budka, A. Wierzbicka-miernik, L. Litynska-dobrzynska, and M. J. Szczerba. "Electrochimica Acta Microstructure Characteristics and Phase Transformations of the Ni-P and Ni-P-Re Electroless Deposited Coatings After Heat Treatment." vol. 209, pp. 183-191, 2016.

[10]. H. Wu, A. Susanto, and K. Lian. "Applied Surface Science Thin and Flexible Ni-P Based Current Collectors Developed by Electroless Deposition for Energy Storage Devices." Appl. Surf. Sci., vol. 394, pp. 63-69. 2017.

[11]. I. E. Ayoub. "Study of Electroless Ni-P Plating on Stainless Steel." no. 1, pp. 13-16.

[12]. E. Mabruri, S. Prifiharni, T. B. Romijarso, and B. Adjiantoro. "Kekerasan Baja Tahan Karat Martensitik 13Cr.”pp. 133-140, 2015.

[13]. P. Suhu, T. Nilai, and D. Dan. "Kandungan Senyawa Asap Cair Hasil Pirolisis.” Skripsi. 2013.

[14]. "pack-carburizing-ugm.pdf." 